\title{
Efficacy of negative pressure wound therapy in the management of acute burns
}

\author{
다 Metin Kement, M.D., ${ }^{1}$ ๑b Adil Başkıran, M.D. ${ }^{2}$
}

${ }^{1}$ Department of General Surgery, University of Health Sciences, Kartal Dr. Lütfi Kırdar Training and Research Hospital, İstanbul-Turkey ${ }^{2}$ Department of General Surgery, İönü University Faculty of Medicine, Malatya-Turkey

\begin{abstract}
BACKGROUND: The aim of the present study was to evaluate the outcomes and efficacy of negative pressure wound therapy in the management of acute burns.

METHODS: Patients with acute burns who have received negative pressure wound therapy at the Dr. Lutfi Kırdar Kartal Research and Training Hospital Tertiary Burn Care Center between January 2014 and December 2015 were included in the study. Patient data were retrospectively reviewed by analyzing data from our prospective patient database.

RESULTS: A total of 38 patients were evaluated for the study. Three patients were excluded due to mortality prior to the completion of the treatment course. There were $32(91.6 \%)$ male and $3(8.4 \%)$ female patients. The mean age of the patients was $49.5 \pm 16$ years. The etiological factors included electrical burn injury in 19 (54.3\%), chemical burn injury in 7 (20\%), flame burn injury in 6 (17.2\%), and hot water burns in $3(8.4 \%)$ patients. The severity of the burns was grade 3 or 4 in all of the patients included in the study. The mean duration of negative pressure wound therapy was $10.1 \pm 3.9$ days. There were no procedure-related complications throughout the duration of the study. During the standard application of the device, one patient experienced local pain; therefore, low pressure $(75 \mathrm{mmHg})$ was applied during therapy, and pressure was steadily increased. As a result of the application of this therapy, a decrease in the surface area, edema, and secretion of the wound and an increase in the granulation tissue and perfusion of the wound were observed in all treated patients. Wound cultures revealed no bacterial growth in any of the patients. The mean duration of surgical wound closure was I I.2 \pm 3.7 days. No complication was observed related to wound closure. The mean duration of hospital discharge in the postoperative period was $6.7 \pm 2.1$ days.
\end{abstract}

CONCLUSION: Well-designed, randomized control studies showing the efficacy of negative pressure wound therapy in patients with burns are lacking. The results of the present study showed that negative pressure wound therapy may reduce the number of wound debridement sessions, time of wound closure, and hospitalization in major burn injuries exposing the underlying tendons and bones.

Keywords: Burn; grafting; negative pressure wound therapy.

\section{INTRODUCTION}

The increased risk of infection and delay in wound healing are the main problems in burns, especially in cases with exposure of the tendon and bone. During the management of such wounds, skin grafts and flaps are used for wound closure. However, occasionally, the condition of the wound in the early phases is not eligible for the application of such therapies. Therefore, long-term open wound care and wound dressings are used as a bridging therapy. In addition, despite adequate therapy, some cases do not meet the adequate conditions for wound closure. ${ }^{[1]}$

Negative pressure wound therapy is a non-invasive therapeutic method that supports the healing of acute and chronic non-healing wounds. ${ }^{[2]}$ It was first described by Argent and

Cite this article as: Kement M, Başkıran A. Efficacy of negative pressure wound therapy in the management of acute burns. Ulus Travma Acil Cerrahi Derg 2018;24:412-416.

Address for correspondence: Adil Başkıran, M.D.

İnönü Üniversitesi Tıp Fakültesi, Genel Cerrahi Anabilim Dalı, Malatya, Turkey

Tel: +90 422 - 34l 0660 E-mail: dr.adil.baskiran@gmail.com

Ulus Travma Acil Cerrahi Derg 2018;24(5):4I2-416 DOI: 10.5505/tjtes.2017.78958 Submitted: 10.12.2017 Accepted: 26.12.2017 Online: 20.03.2018

Copyright 2018 Turkish Association of Trauma and Emergency Surgery 
Morykwas et al. ${ }^{[3,4]}$ in experimental and clinical models and became popular among physicians. The aim of the negative pressure wound therapy is to increase local blood supply, induce granulation tissue formation, and reduce the incidence of infection. ${ }^{[2,5]}$

The aim of the present study was to evaluate the outcomes and efficacy of negative pressure wound therapy in the management of acute burns.

\section{MATERIALS AND METHODS}

\section{Patients}

Patients with acute burns who have received negative pressure wound therapy at the Dr. Lutfi Kırdar Kartal Research and Training Hospital Tertiary Burn Care Center between January 2014 and December 2015 were included in the present study. Patient data were retrospectively reviewed by analyzing data from our prospective patient database. Patients with an American Society of Anesthesiologists IV score, pediatric patients who were $<12$ years old, patients with concomitant organ system injury, and patients who died during treatment were excluded from the study.

\section{Negative Pressure Wound Therapy System}

In the present study, negative pressure wound therapy was applied using the vacuum-assisted wound closure (VAC) system (Kinetic Concept, Inc., USA). The components of the system include a sponge to cover the wound surface, drape to cover the sponge and the wound, connectors between the wound and the device (Therapeutic Regulated Accurate CareT.R.A.C. pad), collectors, and negative pressure device.

\section{Application}

In all patients, escharotomy and wound debridement were performed in the operating room. At the end of the surgical steps, the sponges were shaped according to the size of the wound and used to cover the surface of the wound. The drapes were applied in order to cover the wound and sponges. A hole is punched on the drape, and T.R.A.C. pad is applied. The connectors are applied to the wound and the VAC device. The negative pressure setting is adjusted to 100 $150 \mathrm{mmHg}$, and the device is turned on. The wound dressings were changed once in $72 \mathrm{~h}$. The wound diameter, granulation tissue, and blood supply were evaluated in each wound care session. Wound debridement was applied when necessary. Tissue cultures were obtained whenever the wound dressings were changed. Antibiotic therapy was started and changed according to the results of these cultures. VAC therapy was continued until the wound surface and granulation were eligible for surgical closure methods. In each step, the condition of the wounds was documented.

\section{Study Parameters}

The study parameters included demographic data, such as age and gender, and clinical parameters, such as mechanism of the burn, localization of the wound, duration of VAC therapy, duration of therapy in general, and techniques of final wound closure.

\section{Statistical Analysis}

Continuous data were expressed as mean and standard deviation. Qualitative data were expressed as numbers and percentages. All the statistical procedures were performed using the Statistical Package for the Social Sciences software package version 17.0 (IBM, USA).

\section{RESULTS}

A total of 38 patients were evaluated for the study. Of the patients, three were excluded due to mortality before completing the treatment course. Of 35 patients, 32 (91.6\%) were males, and $3(8.4 \%)$ were females. The mean age of the patients was $49.5 \pm 16$ years. Table I shows the demographic and clinical characteristics of the patients. The etiological factors included electrical burn injury in 19 (54.3\%), chemical burn injury in 7 (20\%), flame burn injury in 6 (17.2\%), and hot water burns in $3(8.4 \%)$ patients. The severity of the burns ranged from grade 3 to 4 in all of the patients included in the study. The mean duration of negative pressure wound therapy was $10.1 \pm 3.9$ days (Table I). No procedurerelated complications throughout the duration of the study were observed. One patient experienced local pain during the standard application of the device; thus, low pressure (75 $\mathrm{mmHg}$ ) was applied during therapy, and pressure was gradually increased. Reduction in the surface area, edema, and secretion of the wound and elevation in the granulation tissue and perfusion of the wound are observed in all patients treated using this therapy (Fig. I). Wound cultures showed no bacterial growth in any of the patients. The mean duration of surgical wound closure was I I. $2 \pm 3.7$ days. There was no complication related to wound closure. The mean duration of hospital discharge in the postoperative period was $6.7 \pm 2$.I days.

\section{DISCUSSION}

Burn injury affects all the physiological systems of the organism, and the patient should be thoroughly evaluated. It
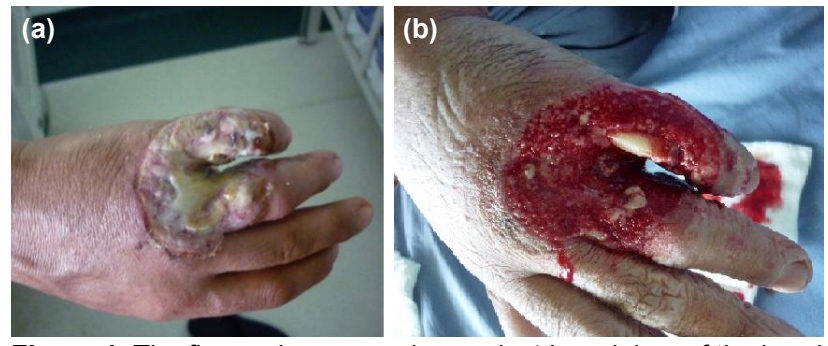

Figure 1. The figure shows a major grade 4 burn injury of the hand exposing the tendon (a) and the condition of the wound after two sessions of negative pressure wound therapy (b). 
Table I. Characteristics of the patients analyzed in the study

\begin{tabular}{|c|c|c|c|c|c|c|}
\hline Diagnosis & Gender & Age & Period of VAC & Affected region & Wound closure technique & Concomitant disease \\
\hline \multirow[t]{6}{*}{ Flame injury } & Male & 29 & $3 \times 3=9$ & Hand-Forearm & Graft & No \\
\hline & Male & 13 & $2 \times 3=6$ & Foot & Graft & No \\
\hline & Male & 36 & $5 \times 3=15$ & Thigh & Graft & No \\
\hline & Male & 35 & $3 \times 3=9$ & Leg & Flap+graft & No \\
\hline & Male & 50 & $3 \times 3=9$ & Forearm & Graft & No \\
\hline & Male & 35 & $4 \times 3=12$ & Bilateral thigh & Graft & No \\
\hline \multirow[t]{19}{*}{ Electric injury } & Male & 65 & $3 \times 3=9$ & Foot & Flap+graft & No \\
\hline & Male & 15 & $7 \times 3=21$ & Foot & Graft & No \\
\hline & Male & 31 & $1 \times 3=3$ & Leg & Graft & No \\
\hline & Male & 23 & $3 \times 3=9$ & Leg & Graft & No \\
\hline & Male & 31 & $5 \times 3=15$ & Foot & Graft & No \\
\hline & Male & 41 & $5 \times 3=15$ & Foot & Graft & No \\
\hline & Male & 51 & $2 \times 3=6$ & Forearm & Flap & No \\
\hline & Female & 52 & $5 \times 3=15$ & Thigh & Flap & Neurologic \\
\hline & Male & 45 & $5 \times 3=15$ & Foot & Graft & No \\
\hline & Male & 70 & $3 \times 3=9$ & Leg & Graft & No \\
\hline & Male & 67 & $4 \times 3=12$ & Bilateral leg & Graft+suture & No \\
\hline & Male & 45 & $2 \times 3=6$ & Arm and forearm & Graft & No \\
\hline & Male & 54 & $2 \times 3=6$ & Leg & Amputation & No \\
\hline & Female & 59 & $4 \times 4=16$ & Foot & Flap+graft & No \\
\hline & Male & 66 & $3 \times 3=9$ & Foot & Flap & No \\
\hline & Male & 55 & $3 \times 3=9$ & Leg & Graft & No \\
\hline & Male & 70 & $3 \times 3=9$ & Foot & Graft & No \\
\hline & Male & 38 & $2 \times 3=6$ & Foot & Graft & No \\
\hline & Male & 70 & $5 \times 3=15$ & Foot & Graft & No \\
\hline \multirow[t]{6}{*}{ Chemical injury } & Male & 55 & $3 \times 3=9$ & Hand & Finger amputation & No \\
\hline & Male & 63 & $3 \times 3=9$ & Elbow+forearm & Graft & No \\
\hline & Male & 68 & $3 \times 3=9$ & Foot & Graft+amput & DM \\
\hline & Male & 55 & $4 \times 3=12$ & Scalp & Graft & No \\
\hline & Male & 58 & $3 \times 3=9$ & Hand & Flap+graft & No \\
\hline & Male & 60 & $3 \times 3=9$ & Foot & Graft & No \\
\hline \multirow[t]{4}{*}{ Hot water burns } & Male & 49 & $3 \times 3=9$ & Forearm & Graft & No \\
\hline & Male & 67 & $3 \times 3=9$ & Leg & Graft & No \\
\hline & Male & 65 & $4 \times 3=12$ & Leg & Graft & DM \\
\hline & Female & 45 & $1 \times 3=3$ & Leg & Flap+graft & No \\
\hline
\end{tabular}

VAC: Vacuum Assisted Wound Closure; DM: Diabetes mellitus.

has a major impact on society and has great morbidity and mortality. Major burns have $6 \%$ mortality even in developed countries. In Turkey, the mortality rate has been reported at $7.5 \%$ in recent studies. ${ }^{[6,7]}$ In the USA, it has been reported that treatment of a patient with major burns costs $\$ 200,000$. Globally, there are multidisciplinary studies that are being performed to increase the efficacy and reduce the costs of burn treatment. ${ }^{[1,8]}$
Tissue injury in patients with burns results in regional edema in the soft tissue. Burn injury leads to capillary leak and results in accumulation of fluids in the interstitial space, resulting in edema..$^{[9]}$ Edema changes the morphology and function of the cells and results in enhanced tissue damage. Edema in the interstitial space causes mechanical compression on the vessel wall and reduces the vascular supply of the tissue. Furthermore, it increases the diffusion distance in the inter- 
stitial space, and all these changes result in cellular hypoxia and progressive tissue damage.

Negative pressure wound therapy reduces edema and results in many physiological changes that enhance wound healing. Morykwas et al. ${ }^{[3]}$ performed Doppler flow meter in a skin defect model and showed that a negative pressure of 125 $\mathrm{mmHg}$ results in four times increase in tissue blood flow. ${ }^{[1]}$ Negative pressure wound therapy enhances tissue perfusion, and capillary density of the tissue increases and results in reduced tissue edema. ${ }^{[10,1]]}$ Mechanical stress to the endothelium results in the secretion of certain cytokines and cellular factors and results in endothelial proliferation and neoangiogenesis. Enhanced perfusion and reduced edema provide a perfect milieu for granulation tissue to develop rapidly. ${ }^{[10,11]}$ Negative pressure wound therapy eliminates local bacteria, reduces proteases that prevent wound healing, enhances wound healing, and reduces healing time. ${ }^{[8-12]}$ The efficacy of negative pressure wound therapy has been proven in patients with diabetic foot and abdominal compartment syndrome. ${ }^{[13]}$

Negative pressure wound therapy has two types of applications in the management of patients with burns. In the initial approach, such as ours, negative pressure wound therapy is applied primarily. In the second approach, it can be applied after grafting of the wound area. ${ }^{[14]}$ Although randomized well-designed studies supporting the primary use of negative pressure wound therapy are lacking, there are many minor reports and case series supporting the efficacy of this approach that reduces the grafting time of the wound. ${ }^{[15]}$ To our knowledge, the present study is the largest case series in the literature that has employed VAC in patients with major burns. Negative pressure wound therapy has enhanced granulation formation, reduced edema, and reduced bacterial load in our series. Only one case reported pain due to the application of standard negative pressure wound therapy, and it was resolved following reduction of pressure in this patient. The major limitation of our study is the lack of a control group due to the retrospective design of the study. Furthermore, we did not obtain tissue biopsy for the histological evaluation of the effects of negative pressure therapy.

\section{Conclusions}

Well-designed, randomized control studies showing the efficacy of negative pressure wound therapy in patients with burns are lacking. The results of the present study showed that negative pressure wound therapy may reduce the num- ber of wound debridement sessions, time of wound closure, and hospitalization in major burn injuries exposing the underlying tendons and bones.

\section{Conflict of interest: None declared.}

\section{REFERENCES}

1. Etöz A, Özgenel GY, Özcan M. Application of Negative Pressured Dressing: Our Clinical Experiences [Article in Turkish]. Türk Plast Rekonstr Est Cer Derg 2004;12:102-5.

2. DeFranzo AJ, Argenta LC, Marks MW, Molnar JA, David LR, Webb LX, et al. The use of vacuum-assisted closure therapy for the treatment of lower-extremity wounds with exposed bone. Plast Reconstr Surg 2001;108:1184-91. [CrossRef]

3. Morykwas MJ, Argenta LC, Shelton-Brown EI, McGuirt W. Vacuumassisted closure: a new method for wound control and treatment: animal studies and basic foundation. Ann Plast Surg 1997;38:553-62.

4. Arcenta LC, and Morkywas MJ. Vacuum-assisted closure: a new method for wound control and treatment: clinical experience. Ann Plast Surg 1997;38:563-77. [CrossRef]

5. Voinchet V, Magalon G. Vacuum assisted closure. Wound healing by negative pressure [Article in French]. Ann Chir Plast Esthet 1996;41:583-9.

6. Monafo WW. Initial management of burns. $\mathrm{N}$ Engl J Med 1996;335:1581-6. [CrossRef]

7. Gomez M, Cartotto R, Knighton J, Smith K, Fish JS. Improved survival following thermal injury in adult patients treated at a regional burn center. J Burn Care Res 2008;29:130-7. [CrossRef]

8. Venturi ML, Attinger CE, Mesbahi AN, Hess CL, Graw KS. Mechanisms and clinical applications of the vacuum-assisted closure (VAC) Device: a review. Am J Clin Dermatol 2005;6:185-94. [CrossRef]

9. Gibran NS, Heimbach DM. Current status of burn wound pathophysiology. Clin Plast Surg 2000;27:11-22

10. Coles DR, Greenfield AD. The reactions of the blood vessels of the hand during increases in transmural pressure. J Physiol 1956;131:277-89.

11. Urschel JD, Scott PG, Williams HTG. The effect of mechanical stress on soft and hard tissue repair; a review. Br J Plast Surg 1988;41:182-6.

12. Li XY, Li WZ, Li YJ, Lv XX, Li J, Chen SZ, Li JQ. The influence of vacuum-assisted drainage on the growth of capillaries in the wound produced by explosion in pig [Article in Chinese]. Zhonqhua Shao Shang Za Zhi 2007;23:292-5.

13. Xie X, McGregor M, Dendukuri N. The clinical effectiveness of negative pressure wound therapy: a systematic review. J Wound Care 2010;19:490-5. [CrossRef]

14. Kamolz LP, Lumenta DB, Parvizi D, Wiedner M, Justich I, Keck M, et al. Skin graft fixation in severe burns: use of topical negative pressure. Ann Burns Fire Disasters 2014;27:141-5.

15. Adámková M, Tymonová J, Zámecníková I, Kadlcík M, Klosová H. First experience with the use of vacuum assisted closure in the treatment of skin defects at the burn center. Acta Chir Plast 2005;47:24-7. 


\section{ORİIINAL ÇALIŞMA - ÖZET}

\section{Akut yanıkların tedavisinde negatif basınçlı yara terapisinin etkinliği Dr. Metin Kement, ${ }^{1}$ Dr. Adil Başkıran²}

1Sağlık Bilimleri Üniversitesi Kartal Dr. Lütfi Kırdar Eğitim ve Araştırma Hastanesi, Genel Cerrahi Kliniği, İstanbul 2İnönü Üniversitesi Tıp Fakültesi, Genel Cerrahi Anabilim Dalı, Malatya

AMAÇ: Bu çalışmada, amacımız negatif basınçlı yara terapisinin (NBYT) akut yanıkların tedavisindeki sonuçları ve etkinliğinin araştııımasıydı. GEREÇ VE YÖNTEM: Bu çalışmaya, Ocak 2014 ile Aralık 2015 tarihleri arasında Kartal Dr. Lütfı Kırdar Eğitim ve Araştırma Hastanesi Yanık Merkezi'nde yanık yarası sebebiyle NBYT uygulanan hastalar dâhil edildi. Hasta verileri ileriye yönelik olarak tutulan bir veritabanı kullanılarak geriye dönük olarak toplandı. Olguların; yaş, cinsiyet, yanık etiyolojileri, yara lokalizasyonları, VAC uygulama süreleri, genel tedavi süreleri, yara kapatma teknikleri geriye dönük olarak değerlendirildi.

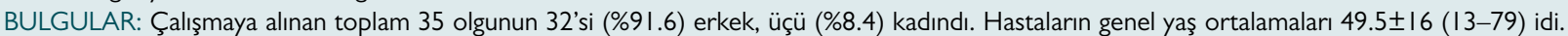
Etiyolojik faktörler sırasıyla 19 (\%54.3) olguda elektrik çarpması, yedi (\%20) olguda temas yanığı, altı (\%।7.2) olguda alev yanığı, üç (\%8.6) olguda sıcak su şeklindeydi. Uygulama yapılan yaraların tümünde yanıklar 3. veya 4. derece idi. NBYT uygulama süremiz en az üç, en çok 16 gün olmak üzere ortalama $10.1 \pm 3.9$ gündü. Hastaların hiçbirinde uygulamaya bağlı komplikasyon gelişmedi. Bir hastamızda standart basınçta uygulama sırasında lokal ağrı gelişmesi üzerine uygulamaya düşük basınç ile $(75 \mathrm{mmHg})$ devam edilerek basınç kademeli olarak artıııldı. Uygulama sonucu tüm hastaların yara alanlarında küçülme, granülasyon dokusunda ve kanlanmada artma, ödem ve yara sekresyonunda azalma gözlemlendi. Hastaların hiçbirinde uygulama bölgesinde bakteriyal üreme tespit edilmedi. Tüm hastaların yaraları cerrahiye uygun olarak değerlendirilerek ortalama II.2 \pm 3.7 günün sonunda greft veya flep yöntemlerinin biri kullanılarak kapatıldı. Hastaların hiçbirinde greft ya da flebe sekonder komplikasyon görülmedi. Hastalar ameliyat sonrası ortalama 6.7 \pm 2.1 (5-9 gün) günde taburcu edildi.

TARTIŞMA: Çalışmamızın bulguları ı̧ı̆̆ında, NBYT'nin iyileşmesi zor, derin, tendon ve kemik ekspoze olmuş yanıklarda yaranın kısa sürede greft ya da flepler ile kapatılmasına olanak vererek, pansuman sayısını ve hastanede yatış süresini azaltabilecek yardımcı bir tedavi seçeneği olabileceği söylenebilir. Ancak, halen daha literatürde NBYT'nin yanıkta kullanımı ile ilgili kanıt düzeyi yüksek ileriye yönelik, randomize, kontrollü çalışma eksikliğinin de mevcut olduğu vurgulanmalıdır.

Anahtar sözcükler: Graft; negatif basınçlı yara tedavisi; yanık.

Ulus Travma Acil Cerrahi Derg 2018;24(5):412-416 doi: 10.5505/tites.2017.78958 